\title{
GOVERNMENTAL LIABILITY IN ORGANIZING ADMINISTRATION FUNCTION IN INDONESIA
}

\author{
by \\ Asep Hidayat \\ UIN Sunan Gunung Djati Bandung Indonesia \\ Email: drasephi62@uinsgd.ac.id
}

\begin{abstract}
Article Info
Article history:

Received July 9, 2021

Revised August 20, 2021

Accepted Sept 11, 2021

\section{Keywords:}

Government responsibility, power, and authority, government functions

ABSTRACT

This research is motivated by the fact that in the State and society, it is still far from expectations; of course, this should be accountable by the government to the people who have voted for it because they have contributed their voices and in other aspects, the community has handed over their power and authority to the government. The problem in this research is that the government's accountability to the community is still low. The purpose of this study is to identify and describe the duties and functions of accountable government administration. This study uses a normative juridical qualitative approach based on legislation. Data collection techniques used are documentation/library studies. The results showed that the function of government administration was not optimal, so it had an impact on the level of public trust in the government.
\end{abstract}

This is an open access article under the CC BY-SA license.

Corresponding Author:

Asep Hidayat

UIN Sunan Gunung Djati Bandung Indonesia

Email: drasephi62@uinsgd.ac.id

\section{INTRODUCTION}

One of the governmental functions is to organize the administration government to increase prosperity by creating jobs available for people to increase income and improve welfare. So that they may gain access to education, availability of health facilities, it was the most urgent needed by society. In addition, it was supported by the prices affordability and evenly and spread distribution of goods. Nevertheless, the reality that occurred in recent years was the opposite, and many people cannot get jobs because many companies laid down their employees (work termination) that they do not have any more jobs, which leads them to become penniless, which in the end society is difficult to get a decent education and other services.

Obviously, these conditions will last in the long term, people are jobless, in this case, this will influence the other aspects. In addition, in the current situation during the pandemic, everything is hard to gain access to education, get jobs, and uneven goods distribution; those were the government's responsibility because power and authority belong to the government. Meanwhile, society does not have it all because they trusted these responsibilities to the government as the authority. Now it is just how the government uses the power and is responsible for carrying out these functions. In the 1945 Constitution, it is clearly stated that as a government instrument has a legal basis that is all government actions conducted, they may not be arbitrary to society and think that they are stupid. People may strike back and do something useful for themselves and their families, and they may not act foolishly as the government did.

Some of the examples carried out by the government, in this case, during the Ied al Fitr celebration, people were urged to stay at home and forbid them to visit each other. Meanwhile, at the same time, they allow workers from China to enter Indonesia because they said that Chinese workers have obeyed health protocol and fulfill immigration requirement data, until today, many Chinese still come to Indonesia. Seeing such conditions, it is as if the Chinese 
were occupying that Indonesian wealth. It is because Indonesia has many debts to the Chinese government. The virus outbreak that occurred has resulted from Chinese and Indian workers' migration to Indonesia. The central government allows them to enter Indonesia so that viruses were spread significantly, and the infection number was increasing instead of decreasing or at the same level. It should be that government protects the Indonesian people, and it seems that what the government did was far from prospering society as mandated in the 1945 Constitution.

The State should protect and create prosperity relatively to society. In that context, a Unitary State of the Republic of Indonesia has an obligation to facilitate every right of its citizens. As a nation aiming to improve public prosperity, as mentioned in the opening of 1945 constitutions, it implies some consequences in organizing the administration; that is, the government must be actively involved in the people's social-economic life-this participation as a form of responsibility to carry the public mission. However, the fundamental problem lately is how laws can give protection, insurance, and legal certainty to society. It was evidenced that the law used as an instrument can be manipulated to deceive society by the ruler. Moreover, the law is also used as an instrument to control the people, to scare them.

In society, those various phenomena show that it still requires a legal instrument that can give legal protection insurance for the authority's actions. This notion development on such legal function is shown with the emergence of the legal state concept, which one of the characteristics is that "governmental liability" that is the ruler's responsibility to account legally the use of power which may harm its citizens. The accountability concept mentioned is a legal responsibility related to the rights and obligations and the government's authority to manage the power in a nation.

With the existence of state legal administration, it was expected that organizing the administration can run as it should be. The state legal administration was expected to make administrative executives' actions well-managed, conforming to the rules and regulations without harming anyone. As people were concerned, many officers' and executives' decisions were still against the law. Either penal law or state legal administration is still regarded as an insignificant matter in this country. On the contrary, those little things can cause massive problems. Therefore, this article will discuss the issue of governmental liability in implementing State legal administration functions.

\section{THEORETICAL FRAMEWORK}

The welfare paradigm emerges as a failure reaction of legal state concept or night watcher State (Nachwastate) or liberating State's and government's role in politics which solely relies on classes aller proposition in forbidding the State and government to interfere people's economic life. And then, it emerges the notion which puts the government as the responsible party for people's welfare.

To support the analysis of one's accountability, which often calls liability and responsibility, refers to accountability in the sense of lawsuit resulting from mistake or negligence conducted by the legal subject, which is interpreted as a responsibility-free from the provisions of laws and regulations. So that the responsibility is defined as a liability concept was related to the one's legal responsibility for specific actions that can be sued legally for the actions against the regulation in administering State and nation.

In essence, responsibility is attached to a title that has been tied up in authority. From a legal perspective, public law is in line with the principle of no authority without accountability. According to Muhamad AK (1999), responsibility theory, in case of violation against the law, was divided into several definitions, such as:

a. Responsibility is due to legal actions that are not done intentionally.

b. Responsibility is due to legal actions conducted based on the concept related to morals and legal, which already blend in.

c. Absolute responsibility is due to the violation against the law without disputing the mistake based on the intentional or unintentional actions.

Thus, fundamentally the state officials must decrease their mistakes either legally or in administering government function because their actions, in the end, must be accountable to the society.

The study of laws and regulations relevant to this article is Public Services Act No. 25 of 2009, is as an effort to increase quality and ensure public service availability conforming to the public administration principles and good governance to protect every citizen and population from abuse of power in administering public services, was required legal setting supporting it.

\section{RESEARCH METHOD}

The research employs a qualitative juridical normative approach based on the constitution. The data used was secondary data in the form of primary laws, a primary legal firm. In collecting literature books for this research, the writer uses document study technique, that is, studying on the documents which closely related to the research object to increase theoretical foundation to ease information in the form of formal text in which the official text existing in the collected material was analyzed qualitatively and presented descriptively. 


\section{RESULT AND DISCUSSION}

\section{Definition of Accountability}

Accountability comes from the work responsible. According to the Indonesian dictionary, responsible is the condition that bears everything it has. Conforming to the general dictionary, responsible is the obligation to bear, to carry, to bear everything it has and the consequences. Responsibility is human consciousness on their behaviors or actions, whether intentionally or unintentionally. A responsible also means to do as the manifestation of awareness or obligation. A responsibility is natural, and it means that it becomes part of human life, that every human was burdened with a responsibility, it is an obligation that must be bear as the performer. Responsibility is that a human feels responsible because they realize the good and bad consequences of their actions and realize that the other party also requires sacrifices.

Ridwan Halim states that Legal responsibility is a further consequence of carrying out the role as the right or obligations/ responsibilities. Generally, legal responsibility is articulated as the obligation to do something or behave conforming to specific ways which did not deviate from the existing regulations. Purbacaraka argues that legal responsibility is sourced from or emerges for using facilities to implement everyone's ability to exercise their rights in carrying out their obligations. He further continues, every implementation of obligation and every rights usage which conducted facilities usage whether it is done inadequately or done adequately basically still has to be accompanied by accountability, as well as the exercise of power. (Mustamu, 2014) it can be interpreted that a president's responsibility to his people is in the form of behavior or words to calm the citizens so that they will not misinterpret the president's gesture because a president's expression is not a God word. Society should interpret this, and it was taken differently by them who say "Lip of Service." It should be that what is said should correspond to the promise of the word is consistent with their doing. It could be said that what is expressed is not a lie, but it is authentic and consistent by reflecting statesmanship required within the society. As in these pandemic times, the authorities should not make the people scarce, so they feel threatened; the president's behavior and word should reflect to protect its citizens. At least during the General election, people choose their leader, do not let them be disappointed by the president's word and decision so that it would not create an anxious mood within the social environment. Moreover, do not let the people be frightened by the leader for using their power in an anti-critical manner by using the judiciary to maintain power so that it lasts so that inappropriate words arise, which comes out inappropriate words. As a result, people deal with the state apparatus (police), which people do not want in this situation. The objective is noble to improve government performance and correct every state agency's assignment, function, and authority.

Government's Responsibility

The government's accountability or Governmental Liability was often exchanged its meaning with the term State Liability, developed by J.J. Van Der Gouw (1997) state. Other opinions developed by Otto Depenheuer (Governmental Liability in Germany, 1997) stated that "the state was liable in public legal law for every state's apparatus actions which make mistakes." "The provision in Article 131 is the actions which proceed civil action which will drag the related officials to face "the civil court." The German Civil Penal Code actions, which are the personal responsibility of the officials (official personnel), are often unsatisfactory so that in turn, it can lead to public distrust of government.

In performing its duty, the government indeed must be accounted for their work result because citizens watch/supervise the job or the fund the government uses to manage the administrations. The supervision is not only internally or by people supervision is accounted for such as blocking roads between regencies, but cities and provinces must also provide reports, everywhere road blockages occur, otherwise there is no need to build it again, especially on the Java and Bali islands. The government forces to get the debt to the Chinese government to make highway roads that will become people's burden. In addition, they are making super-fast train track Jakarta-Bandung on the ground that it will make the people traffic faster, the debt must be paid, this will add people's debt. Government should provide income to unemployed people because many people are having difficulty getting income. It is necessary to build highways, but outside Java-Bali islands still require to build infrastructure facilities. With the blocking of the road, people will eventually not be obedient to the central government because they have given an example of not obeying the rules issued by the government itself so that people see the government's inconsistency in the rules issued.

Accountability conducted by the government is that the action must be helpful and use by many people. It should not otherwise that add more burden to society which has exceeded 1,171 trillion. Undoubtedly, the citizens will bear and have to pay the debts indirectly. If the conditions were today, the government should not build roads and highways, just to be closed to contain virus outbreaks, which will harm the citizens. Every access road and highway were closed, it just wasting money, it is better and more beneficial to use the fund to increase people's welfare. During the pandemic, the government should make policies that do not harm the poor, such as small business enterprises, street vendors, and 
junk scavengers who were miserable because their sales were decreasing. Their family, their children have to eat somehow; they do not have many choices.

Moreover, the Civil Service Police Unit (Satpol PP) officers' attitudes were rude and harsh in dealing with street vendors. In addition, the officers blockade the street with heavy-armed vehicles as if the country is in a war situation. Indeed, society can also be blamed because they lack obedience and discipline to apply health protocol. It means that officers and society should work together and fight back to fix these pandemic situations instead of showing people power by getting more stubborn and disappointed with the officers' behavior during their health protocol discipline enforcement.

Along with the State shifting role as a security and order guardian becomes a welfare state. It means that the president who was selected to improve citizen's welfare was often caused harm to certain parties or the society either directly or indirectly in managing the power for its citizens. It describes as the following findings: (1) government's responsibility should benefit the people as mentioned in the 1945 constitution, not to the global agencies that make a profit to themselves and should defend the citizens, the government should do it, and it did not deviate to 1945 Constitution that is to create a welfare country conforming to the initial concept. Speaking of natural resources, Finland can make the people prosperous from their mining by compensating its citizens. The amount is equal to 2,500,000 IDR; it is just one of the mining industries; however, in Indonesia, not many people relish the natural resources in this vast and prosperous country. (2) Indonesian officials' attitude tends to act arbitrarily; this is shown by the Civil Service Police Unit (Sat Pol PP), they behave arrogantly as shown in Semarang city and Banten Province, they act as if folks do not know or are stupid, but it does not. It shows that the citizens or local civil officers did not respond to the government's lack of sense of humanity or socialization. In these pandemic times, every official was arrogant, every authority, power, and facility were handed by society, and someday the officials' title will quit, and they come back to the community, either due to their period was running out or by death, as if it were none existed?

The illustration describes the ruler's disorder and injustice, showing a disrespectful and arrogant attitude in managing the administration. Basically, the government must ensure serenity, and they must not scare people with this pandemic situation. From the beginning, the disease already existed and life by it as in TBC, influenza virus, cough, and other diseases. They should provide people with an understanding of how to deal with the disease, such as selecting medicine or the available vitamin to avoid the disease impact. Government and medical doctors must cooperate in calming down the people and providing them with good socialization. What is meant by governmental liability is that of the obligation for legal arrangement (compulsory compliance) of the State, governmental official or another executive who run the governmental function as the result of the objection, lawsuit, judicial review, sued by civilians, people, society, the civil legal firm either through court settlement or outside the settlement to fulfill some of the following:

a. Payment sum of money (subsidies, compensation, allowances, etc.)

b. Issuing or canceling/revoking a policy or regulation,

c. Other actions to fulfill the obligations include making more efficient and effective supervision, preventing harm for humans and the environment, protecting people's fortune and properties, managing and maintaining public facilities, imposing sanctions toward a violation or breach, et cetera (Safi, 2010).

\section{CONCLUSION}

Governmental liability is the obligation for legal arrangement (compulsory compliance) of the State, governmental official, or other executives who run the governmental function. As the result of the objection, lawsuit, judicial review, sued by civilians, people, society, the civil legal firm either through court settlement or outside the settlement to fulfill some of the following obligations. That is payment sum of money (subsidies, compensation, allowances, etc.), issuing or canceling/revoking a policy or regulation, and other actions to fulfill the obligations, for instance, to make more efficient and effective supervision, prevent harm for human and the environment, protect people's fortune and properties, manage and maintain public facilities, imposing sanction toward a violation or breach and et cetera.

State officials' attitudes and behavior should not reflect arrogance and arbitrary legal enforcement because they deal with ordinary Indonesian people. They must provide understanding through socialization and explain the main task and authorities of each governmental institution. In doing so, they should not be arrogant and arbitrary but protect and serve the folks as described in their official cars, to serve and protect. In addition, there is a slogan of police helo, whether they have mastered their main tasks and functions and each of their authorities supported with the existing funds. The matter needs to be settled, and the commitment of every institution is needed. People want justice, legal enforcement, and equality before the law principle; those are the solid matters people want in real life or theoretically.

The existence of the governmental liability principle is actually the balancer between the government and the society in managing the State organization. The government has the right to arrange, collect tax, impose a sanction, et 
International Journal of Social Science (IJSS)

Vol.1 No.3 October 2021, pp: 179-184

ISSN: 2798-3463 (Printed) | 2798-4079 (Online)

cetera, which is as set of power implications in the life of a nation. On the other hand, citizens have the right to obtain legal protection from every government action or policy which might cause harm to the people. Therefore, governmental liability actually brings extensive participation by the society within a democratic country to supervise and counter or fix the unjust policies and mistakes conducted by the government.

\section{Suggestion}

Governmental liability is not accessible, particularly in managing administrative functions and its authorities, because government carries people's mandate. Thus, the government must not act arbitrarily in performing the task because, in the end, the government will be accounted for through some of the following ways:

1. The form of governmental liability should be carried out in the House of Representatives (DPR) meeting; the government should carefully execute their primary tasks, authorities function, and responsibilities as excellent and maximum as possible.

2. The government always carries the duty by paying attention to the impact and implication of the action so that they are subjected to be accounted to society, and this mechanism will make people trust the government and obey the policies.

3. Government shows their work result to citizens, this will emerge trust within society to the government in executing the administration duties, and they will always obey the regulation as the legal basis.

\section{REFERENCES}

[1] Ansori, L. 2015. Diskresi Dan Pertanggungjawaban Pemerintah Dalam Penyelenggaraan Pemerintahan. Jurnal Yuridis, 2(1), 134-150. Retrieved from https://ejournal.upnvj.ac.id/index.php/Yuridis/article/view/165

[2] Basah Sjahran,2010 Eksistensi dan tolok ukur Badan Peradilan di Indonesia, Edisi ke 4 Alumni Bandung

[3] Basiang Manan, 2016 The Contemporary Law Dictionary,Edisi ke 2 Pt Gramedia Puataka Utama Jakarta.

[4] Dwiyanto,Agus,2005 Mewujudkan goog governance malalui pelayanan publik UGM Press, Yogyakarta

[5] Farhansyah. (n.d.). Istilah, Pengertian Dan Deskripsi Hukum Administrasi Negara. https://doi.org/10.31219/osf.io/vnfw2

[6] Mustamu, J. 2014. PERTANGGUNGJAWABAN HUKUM PEMERINTAH (Kajian Tentang Ruang Lingkup Dan Hubungan Dengan Diskresi). Sasi, 20.

[7] R, V. 2011. PERTANGGUNG JAWABAN ADMINISTRASI NEGARA. Retrieved May 27, 2021, from Inspirasi Hukumwebsite: http://inspirasihukum.blogspot.com/

[8] R, V. 2011. PERTANGGUNG JAWABAN ADMINISTRASI NEGARA. Retrieved May 27, 2021, from Inspirasi Hukum website: http://inspirasihukum.blogspot.com/

[9] HR, Ridwan 2020. Hukum Administrasi Negara. Depok : PT Raja Grafindo Persersada.

[10] Safi. 2010. Konsep Pertanggungjawaban Perbuatan Pemerintahan sebagai Sarana Mewujudkan Good Governance di Indonesia. Pamator, 3.

[11] Sjamsuddin Indradi, Syamsiar. 2019. Hukum Administrasi Negara. Malang Jatim : Setara Pers.

[12] Surwoto. 1990 . Kekuasaan dan tanggung jawab Presiden, Disertasi Universitas Indonesia,Universitas Airlangga Surbaya

[13] Atmosudirdjo, Prayudi. 1995. Hukum Administrasi Negara. Jakarta : Ghalia Indonesia

[14] Setiawan \& Neru A. 2020. Tanggung jawab jabatan dan tanggung jawab pribadi dalam penggunaan diskresi sebagai instrumen (public service). Jurnal Mimbar hukum 32(1)

[15] Presiden RI. (2009). Undang-undang Nomor 25 Tahun 2009 Tentang Pelayanan Publik.Jakarta: Pemerintah. 
